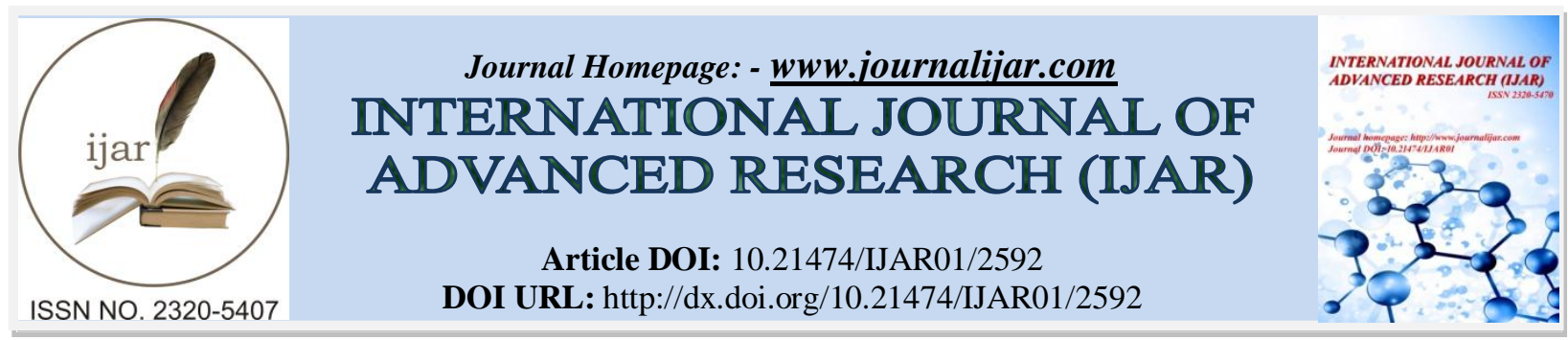

RESEARCH ARTICLE

\title{
“THE DESCRIPTION \& CONCEPT OF NAADI (PULSE)” IN THE SIDDHA SYSTEM OF MEDICINE.
}

Prof. Dr. M.Rajasekaran M.D(S), ${ }^{1}$ and Dr. I. Nithyamala M.D(S $)^{2}$.

1. HOD \& Research Guide, Department of Gunapadam, National institute of Siddha.

2. Research Scholar, Department of Gunapadam, National institute of Siddha.

\section{Manuscript Info}

\section{Manuscript History}

Received: 27 October 2016

Final Accepted: 25 November 2016

Published: December 2016

Key words:-

Siddha, Naadi, Guru Naadi.

\section{Abstract}

The nectar of tamil culture is Siddha system of medicine. It is based on 96 concepts of philosophy. The 96 thathuvam (concepts of philosophy) is the basis for 4448 major classification of diseases. The diagnosis is based on Yen vagai thervu \& the final diagnosis is by the assessment of Naadi (Pulse). The pulse is the individuals Cardio Vascular System represented by the three doshas. The Guru Naadi is used to diagnose the diseases of intra - uterine life, diagnosis \& prognosis etc. The Siddha medical - astrology is the combination of medical concepts inseparable with astrological influence over the health $\&$ disease of the individual.

Copy Right, IJAR, 2016,. All rights reserved.

\section{Introduction:-}

The nectar of tamil culture is Siddha system of medicine. It is based on 96 concepts of philosophy (96 thathuvam ). The disease management is empirical and hypothetical with the combination of Saivism, Vaishnavism, Buddhism, Realism, Meemamsagam, Vaisadeigam, Jainism \& Vedantic concepts.

The arusamaya thathuvam is mentioned in the Siddha system, which includes concepts such as Samana thathuvam says to be detached of pon (Gold), Kalavu (theft), Kathal(Love), Kamam (Sexual Desire) etc. and Saiva thathuvam says to avoid non - vegetarian diet in addition to the above.

The 96 thathuvam is basis for 4448 major classification of diseases in the Siddha system of medicine.

These diseases occurring in of human being were based on 4,00,48,500 Meigal ie genomes, the chemical letters of human beings and innumerable number of Aagamite concepts. The saiva samaya kalanjiyam \& the light of Truth are the core subjects of Siddha and arusamayam describes about genes, codings, chromosomes and pathways etc.

\section{The description \& concept of Naadi (Pulse)}

The Disease diagnosis is based on Yen vagai thervu \& the final diagnosis is by the assessment of Naadi. The The Naadi is nothing but vatham, pitham \& kabam.

The Naadi means Thathu. It indicates the pulses in the blood vessels (arteries \& veins). The Naadi (Pulse) has connections with the heart. We can study the functions of the heart through Naadi (Pulse) [6]. The Naadi 72000 denotes gaseous exchange throughout our system ie is 72000 times/day. The Respiration is about 21600 per day for a healthy adult regardless of age. It may vary in patients with the diseases of the Cardio - Vascular System \& Respiratory System diseases. The Respiratory rate \& heart rate varies in children. In children the values will be little

Corresponding Author:- Prof. Dr. M.Rajasekaran M.D(S).

Address:- HOD \& Research Guide, Department of Gunapadam, National institute of Siddha. 
higher. Pulse rate, respiratory rate \& heart rate will be slightly higher in healthy children; the values fluctuate in children with respiratory system, Cardio - Vascular System, Central Nervous System, Metabolic disorders, Gastro Intestinal diseases, and urinary tract disorders etc.

The pulse is the individuals Respiratory \& Cardio -Vascular System represented by the three dosham; vatham, pitham \& Kabham which helps us for diagnosis \& prognosis. The pulsation includes Arterial pulse \& Venous pulse.

In the blood circulation the deep pulse of the index, middle finger $\&$ ring finger of the subject's right hand in men (left hand in women) on the radial artery pulsation indicates cardio - pulmonary conditions of the health $\&$ disease. The pulsation of this wave goes throughout the body. The Siddha system mentions ten such vital places in our body for pulse examination The pulsation is due to the functional integration of Vatham, Pittam \& Kapham. To get an accurate resting pulse, the pulse should be taken early in the morning in a restful condition.[8]

The healthy pulse varies upto $80 /$ minute or $45 /$ minute in some subjects.[4]

In the naadi paritchai (Pulse examination) according to Saint Theriyar, the gait of mayil (peacock), Annam (swan) \&Kuyil (Cuckoo) are compared to Vatham pulse, the gait of Kozhi (hen), Erumbu (ant) etc are compared to Pitham pulse \& the gait of onaan (Lizard), Ee (House fly) etc are compared to kabam pulse. [9]

In the naadi paritchai (Pulse examination), according to Saint Yugi, the gait of the movement of swing, movement of frog, Lizard, Snake, Leech , Sparrow \& turtle movement represents Vatham pulse, movement of the swan, peacock, bhul bhul, dove, eagle represents pitham pulse, the movement of hen, crane, spider represents Kapham pulse. The combination of Vatham \& pitham vatha pitha pulse \& the combination of Pitham \& Kabham Pithakapha pulse.[10]

Naadi chakkaram[5] indictaes some conditions where pulse diagnosis can be made which includes

1. Initial stages of fever, where the three doshams get altered and fever subsides.

2. Agni Mandham (Indigestion), Agni samamai irutthal - loss of appetite due to Decreased vascular supply to gastric vessels .Loss of appetite results in atrophy of gastric mucosa which may result in Gastric carcinoma etc.

3. Aagarakuraivu (Poor intake of food) - Loss of appetite due to Low HCl secretion - hypochlorhydria, dyspepsia $\&$ anorexia results.

4. Kan vizhithal (Starring of eyes) - Loss of sleep.

5. Kadumaiyana agni (Hyper pyrexia)

6. Bala kuraivu (Lethargy, malaise \& Lassitude)

7. Bayam (Phobia)

8. Dukkam (Depression due to slow vascular supply to Central Nervous System \& anxiety etc.)

9. Manath thadumatram (Schizophrenia \& Mood swings)

10. Intake of tastes such as Kaarppu(Pungency), Kaippu(bitterness), Uppu (Saltishness), Inippu (Sweetness) \& Ushnam (intense heat) alters the pulse.

The Guru Naadi will indicate the life factor or the soul itself [6]. In Agasthiyar guru Naadi Sasthiram [2] (Pulse diagnosis) mentions Guru Naadi is used to diagnose the diseases of intra - uterine life, diagnosis \& prognosis etc. The vatham, pitham \& Kabam \& Guru Naadi is observed, Suzhinai is also related to Guru Naadi. Vatha thotram (formation of Vatham) mentions about the Naadi 10 which again falls into 3 main naadi. The Guru Naadi is formed in the intra uterine life during the time of conception. The mukkutra thathuvam and Dasa naadigal is the basis in the Siddha system of medicine to determine the acute and severity of the Disease. Agasthiyar guru Naadi Sasthiram indicates the diagnosis \& prognosis of the diseases.

According to Aathmaratchamridham ennum vaidya sar sangaragam ,Guru Naadi will be found in front of Pitha Naadi. [1]

In the three naadis, the maathirai beat/pulse for Vatham is one, Pitham is $1 / 2 \&$ for Kabham is $1 / 4$. [3]

The clinical observations are made in the Siddha system of medicine using the Yen vagai thervu which are Naadi, sparisam, naa, niram, mozhi, vizhi, malam \& moothiram along with modern clinical parameters \& clinical pathology parameters like Pulsoxymeter, Doppler, Angiograms etc with the ready availability of records of patients for confirming the diagnosis. Out of the Dasa naadi the first 3 namely Idakalai, Pingalai \& Suzhimunai play an important role in the prolongation of life. In the normal breathing cycle mentioned in the Siddha system of medicine 
21,600 breaths of a human body in a day, the body is utilizing 14,400 breaths oxygen consumption and the balance 7,200 breaths go as waste as carbon - di - oxide by expiration etc. and mixes in the blood as blood gases in the disease.

The agathiyar Thudi nool mentions about the occasional pulsation which indicates the rare events or among self person related with blood relations. Thudi means beat which indicates vibration similar to Pulse rate, Heart rate which are due to vibrations. Due to vibrations heart gives the sound Lub Dub. Thathu is the vital force of the body, life \& function. Sodasam indicates respiration Pooragam, Kumbagam \& Resagam in the ratio 16:32:64. Thudi also means kaala nutpam. The Naadi is related to Udarkattugal. Naadi is related to Udal, Uyir \& Unarvu. The Pathinangu Vegangal (14 natural urges of human body) mentioned in the Siddha literature changes the Naadi. Dasa Naadigal indicates the acute $\&$ severity of the disease.

Pathinen Siddhar naadi sasthiram mentions that pulse should be felt for males on the right hand and for females on the left hand [7]. The radial arterial pulse is monitored below the wrist joint (Aarai Naadi in Siddha system).

The Siddha medical - astrology is the combination of medical concepts inseparable with astrological influence over the health \& disease of the individual. The 360 degree of geo - stationary orbit of earth is divided by 27 constellations of stars, approximately 13.3 Latitude each \& 360 degree is divided by constellation of 12 Rasis of 30degrees longitude each. The living creatures, the entire flora \& fauna are under the direct influence of constellation of stars \& 9 planets of solar family, the galaxy \& the Milky Way. The combination of powerful geo- magnetic rays with the solar \& lunar influence determines the functions of cells, genes covering its preview which determines the personality \& genetic makeup of the individual from the very beginning of the conception $\&$ the end.

\section{Conclusion:-}

The Geo - stationary, astro - magnetic influence \& the response of human body causes disease or healthy well being. This concept has to be evolved on clinical trial to prove it beyond doubt for the benefit of mankind.

\section{References:-}

1. Aathmaratchamridham ennum vaidya sar sangaragam Anonymous Sree Shenbaga pathipagam, Chennai, September 2011, 1st edition Pg 10,11.

2. Agasthiyar guru Naadi Sasthiram Anonymous Senthamizh pathipagam, Chennai, June 2006, Pg 10,11.

3. Agathiyar Poorana Soothiram-216 Guru Naadi sasthiram 235 Matrum Thirumoolar, Agasthiyar, Theriyar Guna vagad thirattu Tamarai Noolagam, Chennai, March 2002, 1st edition Pg 11

4. Hutchison's Clinical Methods Michael Swash Michael Glynn Saunders Elsevier limited 2010 Twenty second edition 2007, Pg 18.

5. Naadi chakkaram Anonymous Saraswathi Mahal Library, Thanjavur, June 2005, $3^{\text {rd }}$ edition Pg 72003.

6. Noi nadal Part I Anonymous Department of Indian Medicine \& Homeopathy Chennai 600106. Pg 95

7. Pathinen Siddhar naadi sasthiram Anonymous Tamarai Noolagam, Chennai, December 1999, Pg 31.

8. Secrets of the Pulse The Ancient art of Ayurvedic Pulse diagnosis Dr.vasant Dattatray Lad Motilal banarsidass Publishers private limited Delhi.

9. Theraiyar Yamaha venba Anonymous Department of Indian Medicine \& Homeopathy Chennai 600106 Pg 17 Second edition 2003.

10. Yugi Vaidiya Chinthamani Anonymous Department of Indian Medicine \& Homeopathy Chennai 600106 Pg 32 , 33, Second edition 2005. 